\title{
Analysis of Factors Influencing Discontinuance of Technology Adoption: The Situation with Some Nigerian Farmers
}

\author{
Mustapha Bello. ${ }^{1}$, Salau E. S. ${ }^{1} \&$ Ezra, L. ${ }^{1}$ \\ ${ }^{1}$ Department of Agricultural Economics and Extension, Nasarawa State State University, Keffi Faculty of \\ Agriculture Shabu -Lafia Campus, Nigeria \\ Correspondence: Mustapha Bello, Department of Agricultural Economics and Extension, Nasarawa State State \\ University, Keffi Faculty of Agriculture Shabu -Lafia Campus, Nigeria. E-mail: elmu457@yahoo.com
}

Received: April 13, 2012 Accepted: May 28, 2012 Online Published: July 30, 2012

doi:10.5539/sar.v1n2p292 URL: http://dx.doi.org/10.5539/sar.v1n2p292

\begin{abstract}
The study identified the factors influencing the discontinuance of improved rice technologies in Nasarawa State of Central Nigeria. Multi-stage random sampling was purposely used to select eighty rice farmers from four rice-producing villages of the study area using structured interview schedule on the respondents. Statistical analysis involving frequency counts, means and percentage were used to satisfy objectives $1,2,3$, and 4 while regression analysis was applied to satisfy objective 5 . The results of the regression analysis showed that education and extension contact had significant but negative relationship at 5\% level; while age had positive and significant relationship at $1 \%$ level with discontinuance of adoption of improved rice technologies. Farmers should be encouraged to participate in the on-going government rural literacy campaign while extension contact be enhanced to minimize discontinuance of improved rice technologies.
\end{abstract}

Keywords: discontinuance, education, extension contact

\section{Introduction}

\subsection{Background of the Study}

After attainment of independence, several projects and programmes were tried by successive Nigerian governments to increase productivity of the agricultural sector of the nation's economy. Among these were Agricultural Development Projects (ADPs) designed in 1975, and partly financed by the World Bank. Other programmes such as the Operation Feed the Nation of Obasanjo's government, Green Revolution of Shehu Shagari's administration and River Basin Development Authorities did not improve the lot of the small-scale farmers. According to Aguene (1998), the programmes failed to achieve the desired objective of self-sufficiency in food production in the country and, also, failed to improve the economic and social well-being of the rural people in particular and other citizenry in general. To achieve self-sufficiency in food production, therefore, a number of production problems had to be tackled through the application of science into agricultural production so that the gap between the high yields available on research stations and the pitifully poor yields recorded on farmers' fields could be minimized.

Experience from results of past government programmes showed that rapid increase in agricultural production in the country was possible only if certain variables (such as access to farm credit, improved seeds, fertilizer, irrigation facilities and plant production measures) were put in place for farmers. Failure to provide these "package" to farmers at sufficient quantity and quality, appropriate time and affordable prices, would prove fatal to the goals and objectives of such programmes. Obeta and Nwagbo (1991) posited that adoption of innovations could be seriously hampered by poor distribution of technological inputs. They further argued that agricultural technologies that were not easily available at moderate prices were hardly adopted.

According to Obinne (1992), the problems of agricultural development in Nigeria was no longer lack of research results but of utilization of research output by end-users as instrument of increased food production as well as for economic development and social progress. This, however, depended to a large extent on the speed with which the technology package was transferred from the source to the ultimate users with clear object that the users understood, accepted and applied it in their day-to-day agricultural practices. In spite of all efforts by concerned agencies to bring scientific discoveries to the door steps of the targeted farmers in Nigeria, the farmers appeared 
not to respond to the waves of changes. Even when such effort existed, according to Ajuomu (1997), there were instances of discontinuance.

Bene et al. (1994) defined adoption process as a mental process, by which an individual went through from hearing about a new idea to the complete and full incorporation of the idea into total system of his behaviour. The conclusion of the adoption process, therefore, was either adopting or rejection of the innovation. An innovation might be adopted but might be rejected at a later date. It was also possible that the innovation would continuously be rejected. Discontinuance of adoption, therefore, was a decision to cease the use of an innovation after previously adopting it for some time.

Nasarawa Agricultural Development Programme (NADP) continued to promote widespread campaign for the adoption of improved rice (ITA 257 and NERICA 40) technologies with high yielding productivity and processing techniques among small scale and medium rice farmers in the state, due to its importance as food security and as cash crop in the country. Rice crop served multi- purpose roles: it immensely contributed to internal and external African sub-regional trade as well as food security for the nation. Rice contribution to the nation's economy had been on the increase over the years (Akpokodje et al., 2001; World Bank, 1996). As a result of the nation's urbanization, rice constitutes a major portion of the expenditure of cereals based diets of most Nigerians. However, over the years, rice production had been found to be inadequate to the extent of not being able to bridge the demand/supply gap thereby causing the country to result to importation. Akpokodje et al. (2001) reported that 34.4 million Naira was spent on rice imports between 1995 and 1999.

At present, there are improved rice varieties and other associated complementary technologies in the country but their widespread adoption have not been taking place. This is what makes this study necessary and relevant. The purpose of this study was to analyze factors influencing the discontinuance of adoption of improved rice technologies by resource-poor farmers in Nasarawa State of Central Nigeria.

The specific objectives were to:

1. describe the socio-economic characteristics of rice farmers in Nasarawa State.

2. identify the improved rice production technologies available in the study area.

3. identity the improved rice production technologies adopted and later discontinued by farmers.

4. determine reasons for the discontinuance of adoption of the technologies.

5. determine the relationship between farmers socio-economic characteristics and the discontinuance of the adopted rice technologies in the study area.

\section{Methodology}

\subsection{Description of the Study Area}

Nasarawa State is located at the central part of Nigeria. The State shares the same border with Federal Capital Territory of Abuja and Bauchi, Taraba, Benue, Kwara and Kaduna States to the sourth-west, north-east, east, south, south-west and north-west respectively. Major occupation of the people is farming. The vegetation of the state has been largely modified by farming activities in the northern areas. A greater part of the southern area is characterised by the guinea savannah type and predominantly derived savannah. Nasarawa State is endowed with abundant water resources with estimated water surface of above 5,656 hectres (MCI, 2000). The farmers in Nasarawa State grow varieties of crops such as beniseed, cassava, yam, rice, melon seed, mango and oranges. They are also involved in raising livestocks including cattle, sheep, goats, sigs and poultry. Fisheries farming is also substantially undertaking by most farmers. It is, however, important to note that rice farmers in rice-producing areas have long been involved in producing local varieties with their attendant low yield. The state has a population of 1,863,276 (NPC, 2006) with estimated 180, 433 farm families (NADP, 2000). The major ethnic groups residing in the Nasarawa State include, Eggon, Mada, Alago, Hausa/Fulani, Gwandara, Tiv, Rindre, Kanuri, Migili, Akye, Afo, Egbira Gade and Gbagi.

\subsection{Sampling Technique and Sample Size}

A two-stage sampling technique was used to source respondents for the study. First four (4) villages were purposively selected out of seven (7) villages (Azara, Awe, Tunga, Adudu, Obi, Keana, and Kadarko) noted for the production of rice in the state. In the second stage twenty (20) rice farmers from each of the village randomly selected, making a total of eighty (80) respondents for the study.

\subsection{Data Collection}

Primary data were collected with the aid of an interview schedule administered on the rice farmers by the 
researcher in the study area. Secondary data were, also, collected from periodic reports of the NADP and respective local government areas. Data were collected over a period of three (3) weeks during the planting season of 2011.

\subsection{Analytical Techniques}

Simple descriptive statistics such as means, percentage and frequency counts were used to satisfy objective 1-4 while regression analysis was applied to achieve objective five (5). Regression analysis was used to show the contribution of the socio-economic variables of the respondents to their discontinuance of improved rice varieties.

The model is described thus:

$\mathrm{Y}=\left(\mathrm{a}+\mathrm{b}_{1} \mathrm{X}_{1}+\mathrm{b}_{2} \mathrm{X}_{2}+\mathrm{b}_{3} \mathrm{X}_{3}+\mathrm{b}_{4} \mathrm{X}_{4} \ldots \ldots\left(\sum \mathrm{ij}\right)\right.$

Where $\mathrm{Y}=$ level of discontinuance

$\mathrm{a}=$ constant term

Age $(\mathrm{X})$ (years)

Education $\left(\mathrm{X}_{2}\right)$ (years)

Household size $\left(\mathrm{X}_{3}\right)(\mathrm{No})$

Social participation $\left(\mathrm{X}_{4}\right)$ (years)

Farming experience $\left(\mathrm{X}_{5}\right)$ (years)

Farm size $\left(\mathrm{X}_{6}\right)(\mathrm{Ha})$

Farmers' income $\left(\mathrm{X}_{7}\right)(\mathrm{N})$

Extension contact/visit $\left(\mathrm{X}_{8}\right)$ (No of Contact/result)

\section{Results and Discussion}

\subsection{Socio-economic Characteristics of Survey Farmers}

All survey farmers were male while $95.0 \%$ of them were married. Mean age of respondents was 45 years (Table 1) suggesting that the farmers were generally of middle age. The results inferred that a man must be married before being socially considered as adult. This agreed with Ani (2004) who reported that until a man was married, he had the right to be fed by his mother, and as far as the society was concerned he had no need of his own. Okeowa et al. (1999) reported that in Nigeria, agricultural production was still being carried out using physical strength, which declined with age.

About seventy percent of the respondents had no formal education (Table 1), implying that majority of the survey rice farmers did not go to school at all and therefore illiterate. Such low level of formal education of the respondents inferred their inability to understand scientific basis of agricultural practices over their traditional system. This agreed with Idris et al. (2006) who identified low level of formal education to be associated with less likelihood of respondents to understand the scientific basis of agriculture and superiority of improved practices over their traditional practices. The study further revealed that rice production was male dominated.

Average household size was 11 (Table 1) and, therefore, large. This consisted of one wife, eight children and two dependents. According to Njoku (1991), households with larger size tended to attach greater importance to food security than those that were small in size. Agbamu (2006) opined that farmers who perceived high risk associated with adoption of new farm practices usually became reluctant to adopt them. According to Ogunfidimi (1981), farmers tended to reject an innovation if the unforeseen profits from adoption of a new farm practice did not exceed the ones obtainable without the innovation sufficient enough to justify the extra risks.

The results of the study (Table 1) also revealed that $77.5 \%$ of the respondents were members of cooperative societies. Cooperative membership enhanced access to information for members on improved technology, and many other inputs of the technologies. Njoku (1991) also opined that farmers who were members of cooperative organizations adopted more technologies than non-members. Williams et al. (1984) posited that the success of many programmes depended on the approval of formal and informal leaders of the community. These leaders, according to them, were expected to give approval to many ideas and packages that were to be adopted by people. If these leaders had no innovative spirit, they concluded, their followers should not be expected to adopt any new recommended practice. 
Table 1. Socio-economic characteristics of rice farmers

\begin{tabular}{ccc}
\hline Variables & Frequency & Percentage \\
\hline Age & & \\
$20-30$ & 1 & 1.25 \\
$31-40$ & 17 & 2.25 \\
$41-50$ & 55 & 68.75 \\
$51-60$ & 5 & 2.25 \\
61 and above & 2 & 2.50
\end{tabular}

Education Level

Adult Education

11

13.75

Primary education

6

7.50

SSCE

0

0

Diploma/NCE

HND/B.Sc.

0

0

Non-formal

2

2.5

Household Size

$\begin{array}{ccc}1-5 & 1 & 1.75 \\ 6-10 & 41 & 51.35 \\ 11-15 & 11 & 18.75 \\ 16-20 & 5 & 6.25\end{array}$

Membership of Cooperatives

$\begin{array}{cll}1 & 18 & 3.75 \\ \text { None } & 62 & 77.5\end{array}$

Marital Status

$\begin{array}{ccc}\text { Married } & 76 & 95.0 \\ \text { Single } & 1 & 1.25 \\ \text { Widow } & 3 & 1.25\end{array}$

Source: Field survey, 2011

Table 2. Distribution of rice farmers and extension visits

\begin{tabular}{llll}
\hline Visits & Frequency & Day of the Week & Percentage \\
\hline Once a week & 25 & Monday & 31.75 \\
Once in 4-weeks & 30 & Tuesday & 37.75 \\
Occasionally & 10 & Wednesday & 12.50 \\
Others (specify) & & & \\
(any day of the week) & 15 & Thursday & \\
Total & 80 & & 100.00 \\
\hline
\end{tabular}

Source: Field survey, 2011

\subsection{Distribution of Respondents and Extension Contact/Visit}

The results of the study revealed that $25.0 \%, 30.0 \%, 10.0 \%$ and $15.0 \%$ of the respondents reported receiving visit/contact from extension agents once a week, once in four weeks, occasionally and "any day of the week" 
respectively. Visits, according to Benor and Baxter (1984), must be regular, specific and purposeful. The findings in the study area, however, confirmed the fact that the visit by an extension agent was not regular, specific and purposeful. This implied that survey rice farmers were generally not aware of the visit days. Benor and Baxter (1984), also, reported that field visit was designed to advise and teach proven recommendations and to encourage farmers to adopt in. They advised that visit was made to help to establish in research and extension an awareness of actual farmers condition and need.

Adoption involved acceptance and repeated use of an innovation since the new practice brought an improvement on farm productivity or expected to do so or helped to ease difficult farm operation (USANCRC, 1995). However, when people accepted innovation they tended to remain curious until it had worked for some time and proved reliable. Agbamu (2006) believed that to ensure that farmers sustained the adoption of an innovation and the adoption of an innovation and not to revert to old methods, there was a need for regular reinforcement of promotional campaign about the good aspects of the innovations. He, however, argued that through emergence of a superior innovation, farmers might discontinue the use of previous innovation as they constantly sought better ways of doing things.

\subsection{Sources of Information on Improved Rice Technologies}

The results of the study (Table 3) showed contact farmers and extension agents were the major sources of information on improved rice technologies by $50.0 \%$ and $17.5 \%$ of the respondents respectively. These information sources could be described as personal information sources. Agricultural show, an impersonal source of information attracted only $1.3 \%$ of the respondents' attention. The primary goals of these information sources were to create awareness by way of diffusing among potential rice adopters useful and practical information on improved rice technologies and to encourage them to adopt them. The major reasons for the involvement of the personal channels were to ensure face-to-face interactions between sender and receiver and the reaction to sender feedback (Katz et al., 1963). The results of the study inferred that personal information sources such as extension agents/workers and contact farmers were effective in disseminating a complexity of information like technology package. Therefore, both the contact farmers and extension agents constituted the most important sources of information to the survey rice farmers as $65.0 \%$ of them obtained information on improved rice technologies from the sources. These personal channels of communication, however, had the disadvantage of being expensive and could only reach a few persons at specified time.

Table 3. Distribution of respondents based on information sources

\begin{tabular}{lll}
\hline Sources of Information & Frequency & Percentage \\
\hline Contact Farmers & 40 & 50.00 \\
Extension agents & 30 & 17.50 \\
Fellow farmers/Neighbours & 5 & 6.25 \\
Field visit & 4 & 5.00 \\
Agricultural Show & 1 & 1.25 \\
Total & 80 & 100.00 \\
\hline
\end{tabular}

Source: Field survey, 2011

Table 4. Distribution of respondents in accordance with compatibility of new ricetechnology with local practice

\begin{tabular}{lllll}
\hline Technology & Compatibility & \multicolumn{3}{l}{ Not-Compactable } \\
\hline Contact Farmers & Frequency & Percentage & Frequency & Percentage \\
ITA 257 & 75 & 92.5 & 6 & 7.5 \\
NERICA 40 & 60 & 62.5 & 30 & 37.5 \\
Use of Tractor & 75 & 92.5 & 6 & 7.5 \\
Fertilizer Application & 65 & 81.25 & 15 & 18.75 \\
Herbicide Application & 80 & 100.00 & 0 & 0.0 \\
\hline
\end{tabular}

Source: Filed survey, 2011; Multiple Response 
One of the primary duties of agricultural extension agencies, according to Rogers and Shoemaker (1993), was the promotion, with encouragement of the adoption of innovations. They maintained that the consequence of diffusing event was mainly taken to refer to the later history of use or disuse, if adoption was to take place. Because diffusion of innovation would normally involve different communication sources, that might help to be important for the decision to adopt or not to adopt while experience of use might provide the main source of confirmation to continue to adopt, discontinue adoption, continue to reject or later adopt.

\subsection{Compatibility of Improved Rice Technology with Local Practice}

The data at Table 4 show the distribution of respondents in accordance with compatibility with existing local practices in the study area. The results showed that all the rice technology package available was observed to be compatible with local practices. This inferred that the rice technology package introduced into the study area was compatible with cultural environment of the farming community. Olawoye (1990) reported instances in which farmers resisted innovations that were not congruent with cultural patterns of the people. According to Chamala (1987), community norms were unwritten laws influencing the behaviour of farmers and others. He described belief as knowledge and information a person assumed to be true about the environment, while value orientations, he argued was generally feelings about what was desirable or understandable. Chamala (1987) reported that opinion leaders upheld or created new norms in a community and it was important to locate them and got them on our side by providing them information on new technology.

The findings of the study further confirmed cases of discontinuance of adoption of those technology not to be compatible with the local practices of the rice farmers in the case of NERICA 40. By inference, therefore, technologies earlier considered compatible by farmers would suffer less continuance than those regarded not compatible with their local practice.

\subsection{Distribution of Respondents in Accordance with Adoption and Discontinuance of Improved Rice Technology Package}

The results (Table 5) showed that all the respondents adopted fertilizer application while $37.5 \%$ of them discontinued its adoption. In terms of the ranking order, use of Tractor had the highest order of discontinuance as claimed by $77.0 \%$ of the respondents. In the same vein, only $21.25 \%$ of the survey farmers discontinued adoption of ITA 2.57 variety. Similarly, fifty percent of the respondents discontinued adoption of spacing technology.

Table 5. Distribution of respondents based on adoption and discontinuance improved rice technology

\begin{tabular}{lllllll}
\hline Technology & \multicolumn{2}{l}{ Previously Adopted } & \multicolumn{2}{l}{ Presently Adopted } & \multicolumn{2}{l}{ Discontinuance } \\
\hline & Frequency & Percentage & Frequency & Percentage & Frequency & Percentage \\
ITA 257 & 77 & 96.25 & 60 & 75.00 & 17 & 21.25 \\
NERICA 40 & 60 & 75.00 & 0 & 0.00 & 60 & 75.00 \\
$\begin{array}{l}\text { Use of } \\
\text { Tractor }\end{array}$ & 68 & 85.00 & 6 & 7.5 & 62 & 77.50 \\
$\begin{array}{l}\text { Fertilizer } \\
\text { Application }\end{array}$ & 80 & 100.00 & 80 & 100.00 & 30 & 37.50 \\
$\begin{array}{l}\text { Herbicide } \\
\text { Application }\end{array}$ & 68 & 81.25 & 20 & 25.00 & 60 & 75.00 \\
Spacing & 71 & 88.75 & 50 & 62.50 & 40 & 50.00 \\
\hline
\end{tabular}

Source: Filed survey, 2011; Multiple Response

According to Yates (1995), technology could be transferred primarily through authoritarian imposition and through voluntary or emulation. He believed that technology that were transferred through authoritarian imposition were not stable because once the coercion was withdrawn or relaxed the adoption of the technology would be discontinued. Adoption by voluntary methods (means) as the case in the study area, he further claimed, depended on the effectiveness of demonstration which might be rapid or slow. Bello (2007) reported that extension workers in the study area had excessively large jurisdiction. In addition, the extension workers lacked vehicles to ensure adequate mobility. Under these circumstances, he argued, extension workers were often 
unable to reach majority of farmers regularly. Consequent to this, Bello (2007) further argued, farmers could reject many apparently attractive and supposedly appropriate technologies either through non-adoption or discontinuation of earlier technologies because they were not really appropriate or that the method of technology transfer was not adequate.

In a number of cases many farming communities were encouraged to adopt improved technologies but the response was poor. Yates (1995) opined that the approach employed was the use of cash incentive and food-for-work to encourage farmers to adopt. The problem with this approach, he maintained, was reported to lead to farmers abandoning the technology when funds or other incentives dried up. Bello (2007) observed in the study area $25.0 \%$ of the extension workers claimed to be satisfied with payment of their allowances, while $80.0 \%$ of them shared the same view on payment of their salaries. He, therefore, discovered that government subventions hardly extended beyond the payment of personnel emolument. This situation according to him, was bound to affect adversely the critical activities of the study area such as adoption of new innovations.

\subsection{Reasons for Discontinuance of Improved Rice Technologies}

The data at Table 6 show the basis of discontinuance of adoption of the improved rice technologies by the respondents. About $21.5 \%, 75.0 \%, 37.0 \%, 75.0 \%$, and $50.0 \%$ of the respondents attributed reasons for the discontinuance of the improved rice technologies to unavailability of improved seed varieties of ITA 257 and NERICA, 40, inability to secure the use of tractor, inability to purchase fertilizer and herbicides as well as the cumbersome nature of manual operation of the recommended spacing technology respectively. Even though the improved rice varieties of ITA 257 and NERICA, 40 were reported to be of early establishing and early maturing characteristics, they were, however, observed not only to provide low tillering, low yield but also difficult to thresh by the resource-poor rice producers.

Table 6. Regression analysis for the factors influencing discontinuance adoption of improved rice production

\begin{tabular}{lllll}
\hline & \multicolumn{2}{l}{ Unstandardized Coefficient } & t-Value & Sign \\
& $\mathrm{B}$ & Std error & & \\
\hline Constant & 534 & 283 & 1.887 & .063 \\
Age $\left(\mathrm{X}_{1}\right)$ & $4.665 \mathrm{E}-03 *$ & .013 & .365 & .006 \\
Education $\left(\mathrm{X}_{2}\right)$ & $-9.847 \mathrm{E}-03^{* *}$ & -013 & .754 & .015 \\
Household Size $\left(\mathrm{X}_{3}\right)$ & $7.44 \mathrm{E}-03$ & .009 & .799 & .127 \\
Social Participation $\left(\mathrm{X}_{4}\right)$ & $5.930 \mathrm{E}-02$ & .079 & .754 & .483 \\
Farming Experience $\left(\mathrm{X}_{5}\right)$ & $-1.346 \mathrm{E}-03$ & .012 & .110 & .913 \\
Farm Size $\left(\mathrm{X}_{6}\right)$ & $1.190 \mathrm{E}-02$ & .030 & .398 & .694 \\
Farmer's Income $\left(\mathrm{X}_{7}\right)$ & $4.811 \mathrm{E}-07$ & 000 & .360 & .791 \\
Extension Contact $\left(\mathrm{X}_{8}\right)$ & $-1.415 \mathrm{E}-02 * *$ & .033 & .420 & .049 \\
\hline
\end{tabular}

R2 $=0.67 ; *$ Significant at $1 \% ; *$ Significant at $5 \%$

Constraints to continuation of adoption of rice technology due to lack of access to the seed varieties by $96.25 \%$ of the respondents suggested that these improved varieties were in short supply, or that extension workers failed to educate the survey farmers to alternative sources of these varieties or lack of decentralization of sale points or a combination of the two. Similarly, in a number of cases the problem of discontinuous with the adoption of technology was attributable to the characteristics of the technology itself. Like in the case of study area Williams et. al. (1984) opined that if the recommended practice was relatively easy to follow and visible, it was likely to be more accepted than one that had to undergo a lot of complex processes. Nwike and Chidebelu (1991) identified lack of funds as an important constraint to continuous adoption of innovation especially in the case of fertilizer acquisition because of non-divisibility of fertilizer (one 50kg bag or nothing) in Nasarawa State and the high "black market", which according to them, of retail price, made nonsense of government subsidies. They also claimed that technology was easier to adopt if it was divisible, did not involve major changes in the farmers' ways of doing things, and was not expensive to the farmers. About $77.5 \%$ of the respondents in the study area claimed high cost of technology constituted significantly to constraining rice farmers from adopting the improved rice technologies. 


\subsection{Regressing Analysis for Factors Determining Discontinuous Adoption of Improved Rice Technology}

Table 7 shows that age, education, household size, social participation, farming experience, farm size, farm income and extension contact were all significant determinants of discontinuous of adoption of improved rice technologies. the coefficient for age was significant at $1 \%$ level while education was significant at $5 \%$ level and together with other significant variables accounted for about $67.0 \%$ of the variability in the level of discontinuous of technology adoption.

Table 7. Details of reasons for discontinuance

\begin{tabular}{lllllllll}
\hline Technology & \multicolumn{2}{l}{ Lack of Funds } & \multicolumn{2}{l}{ Unavailability of Inputs } & \multicolumn{2}{l}{ Cost of Technology } & \multicolumn{2}{l}{ Tediousness } \\
\hline & Frequency & $\%$ & Frequency & $\%$ & Frequency & $\%$ & Frequency & $\%$ \\
ITA 257 & - & & 17 & 21.25 & & & & \\
Nerica 40 & - & & 60 & 75 & & & \\
Use of Herbicide & 60 & 75 & - & - & & & \\
Use of Fertilizer & & & 30 & 37.5 & - & - & - \\
Use of Tractor & - & - & - & & 62 & 77.5 & & \\
Spacing & - & - & - & - & - & - & 40 & 50 \\
\hline
\end{tabular}

\section{Conclusion and Recommendations}

\subsection{Conclusion}

Low level of rice farmers' education, their low level of technical know-how, and poor method of technology transfer in the study area contributed significantly to discontinuance of adoption of improved rice technology into practical reality. Other farmers' characteristics such as age, household size, social participation, farming experience, farm size, farm income and extension contact accounted for $67.0 \%$ variation in discontinuance of adoption of improved rice technology by farmers.

\subsection{Recommendations}

In line with the foregoing conclusion, this study recommends

a. extension service system should be designed to cooperate with research in

developing farmer's need based and tailored technologies.

b. extension message should be made simple and more relevant to enable farmers

understand technical implication of the introduced technologies.

c. number of and specialized extension workers be provided, while frequency of extension visits be enhanced to minimize occurrences of discontinuance of adoption among rice farmers.

d. financial incentives, especially payment of staff allowances be enhanced so as to eliminate cases of complacency and truancy among extension workers.

e. literacy level of the targeted farmers be enhanced through periodic holding of workshops and in-service training to help uplift farmers' technical-know-how of the improved technology.

f. sources of inputs to complement recommended technology package be employed to expand farmers' scope of acquisition of such recommended inputs on time and at affordable prices.

\section{References}

Agbamu, J. U. (2006). Essentials of Agricultural Communication in Nigeria (1st ed.). Benin: Malthouse Press Limited (Chapter 4).

Aguene, I. N. (1998). Rural Development in Rural Sociology: An African Perspective: Nsukka, Price Publishers (Chapter 6).

Ajuonu, J. A. (1997). Discontinuance of Paddy Rice Production Technologies by Small Scale Farmers in Benue State: A Case Study of Guma Local Government Area. Unpublished B. Agric Project Report at department of Agricultural Economics and Extension. University of Agriculture, Makurdi (Chapter 4). 
Ani, A. O. (2004). Women in Agriculture and Rural Development (1st ed.). Maiduguri Danladi Press (Chapter 4).

Akpokodje, G., Hamicon, F., \& Erestein, O. (2001). Nigeria's rice economy: State of Act. Proceeding of Annual meeting of Farm Management Association of Nigeria (FAMAN). Jos, Nigeria.

Bello, M. (2007). Extension Services in Central Nigeria: Perception of Extension Workers. International Journal of Labour and Organizational Psychology, 1(2), 165-172.

Bene, J. K., Obinne, C. P., \& Apkehe, A. A. (1994). Agricultural Extension in Rural Development. Makurdi; Benue State: Almond Press (Chapter 5).

Benor \& Baxter. (1984). The Training and Visit Extension. Washington D. C: The World Bank (Chapter 3).

Chamala, S. (1981). The Essentials of Agricultural Communication in Nigeria. Benin: Malthouse Press Limited (Chapter 6).

Idrisa, Y. C., Gwacy, M. M., \& Ibrahim, A. (2006). Determination of Adoption of Cassava Farming. Production Agriculture and Technology (PAT), 2, 26-36.

Katz, E., Levin, M. I., \& Hamilton, H. (1963). Traditions of Research on Diffusion of Innovations. American Sociological Review, 237-252. http://dx.doi.org/10.2307/2090611

Ministry of Commerce and Industries. (2000). Investment Opportunities in Nasarawa State. Lafia: Nasarawa State, 1,30 .

Nasarawa Agricultural Development Programme. (2000). Annual Situation Report. Lafia: NADP. pp. 1-25.

National Population Commission. (2006). National Population Census Report. Abuja-Nigeria.

Njoku, J. E. (1991). Factors Influencing the Adoption of Improved Oil Palm Production Technologies by Small-holders in Imo State, Nigeria. Proceeding of 4th National Conference of Farming Systems Research Network. Calabar, Nigeria.

Nwike, C. C., \& Chidebelu, A. A. (1991). Appraisal of Yam Minisett for Farmers in South-Eastern Nigeria. Proceedings of 4th Conference of National Farming System Research Network Calabar, Nigeria.

Obeta, M. E., \& Nwagbo, F. C. (1991). The Adoption of Agricultural Innovations in Anambra State, Nigeria: A Case Study of Improved IITA Cassava Technology Package. Proceedings of 4th Conference of National Farming System Network Calabar, Nigeria.

Obinne, C. P. O. (1992). Effective Communication in Agricultural Productivity. Journal of Rural Development and Administration, 12(4), 1-8.

Ogunfiditimi, T. O. (1981). Adoption of Improved Farm Practices: A Case under Uncertainty. Indian Journal of Extension Education, XV1I (1 \& 2), 30-35.

Ohewo, T. A., \& Adeyemi, L. A. (1991). An Assessment of the level of Innovation of Farm-Children. Proceeding of $2^{\text {nd }}$ Annual Conference of Children-in-Agriculture Enugu, Nigeria.

Olawoye, J. E. (2006). Essentials of Agricultural Communication in Nigeria. Benin: Malthouse Press Limited, Benin. (Chapter 4).

Rogers, E. M., \& Shoemaker, F. F. (1971). Communication in Agriculture. New York: The Free Press.

William, S. K. (1978). Rural Development: An Introduction. London: Macmillian Press Ltd. p. 210.

Williams, S. K. T., Fenley, J. M., \& Willaims, C. E. (1984). A Manual for Agricultural Extension Workers in Nigeria. Ibadan: Less Shyraden Publisher.

World Bank. (1986). World Development Report. Oxford University Press.

Yates, R. A. (1995). Methods for Technology Transfer for Agricultural Development in Sub-Saharan Africa. Agricultural Extension in Nigeria (3rd ed.). Ilorin, Nigeria. 